\title{
KORELASI ANTARA STATUS GIZI IBU MENYUSUI DENGAN KECUKUPAN ASI DI POSYANDU DESA KARANG KEDAWANG KECAMATAN SOOKO KABUPATEN MOJOKERTO
}

\author{
Correlation Between Breastfeeding Mother Maternal Nutrition Status With Breastfeeding \\ Adequacy In Posyandu of Karang Kedawung, Sooko, Mojokerto
}

\author{
Nurul Pujiastuti \\ Program Studi Keperawatan Lawang Poltekkes Kemenkes Malang \\ Jl. A. Yani No 1 Lawang 65218 \\ e-mail: nurulpujiastuti@gmail.com
}

\begin{abstract}
ABSTRAK
Masalah gizi di Indonesia dan negara berkembang umumnya masih didominasi oleh masalah kurang energi protein (KEP), anemia besi, gangguan akibat kekurangan yodium (GAKY), kekurangan vitamin A (KVA) dan masalah obesitas. Anemia umumnya dijumpai pada golongan rawan gizi yaitu ibu hamil, ibu menyusui, anak balita serta anak sekolah. Anemia atau gizi yang buruk pada ibu menyusui akan menyebabkan gangguan nutrisi dan produksi air susu ibu (ASI) menjadi kurang sehingga menimbulkan gangguan pertumbuhan bayi. Penelitian ini bertujuan mengetahui korelasi antara status gizi ibu menyusui dengan kecukupan ASI. Status gizi diukur dengan 3 indikator: IMB, LILA, dan Hb. Sedang kecukupan ASI diukur dengan indikator: tanda kecukupan ASI, BB bayi sebelum dan sesudah menyusu serta peningkatan BB bayi setelah 1 bulan. Penelitian ini menggunakan rancangan longitudinal (cohort). Hasil uji analisis statistik dengan mann whitney u test didapatkan tingkat signifikansi $95 \%(\mathrm{p}=0,009)$. Hasil uji analisis ditemukan tidak ada korelasi antara status gizi ibu menyusui (IMB dan LILA) dengan kecukupan ASI. Tetapi terdapat korelasi antara kadar $\mathrm{Hb}$ dengan kecukupan ASI. Kesimpulannya bahwa ibu menyusui dengan gizi buruk akan mempengaruhi kecukupan ASI karena tubuh membutuhkan zat gizi yang cukup untuk memproduksi ASI, tetapi tubuh tidak dapat memenuhi sehingga zat gizi tersebut diambil dari tubuh ibu dan berakibat makin lama ibu akan mengalami gizi yang bertambah buruk.
\end{abstract}

Kata kunci: status nutrisi, ibu menyusui, kecukupan ASI

\begin{abstract}
Problem of gizi in Indonesia and developing countries in general still predominated by problem less energi protein, iron anaemia, trouble effect of iodine insuffiency, lacking of vitamin of A and problem of obesitas especially in metropolis. Anaemia of gizi is generally met at gristle faction of gizi that is pregnant mother, mother suckle, child of balita and also schoolchild. Anaemia at mother suckle will cause trouble of nutrisi production and irrigate mother milk become less. this clear generate growth trouble for baby which in giving irrigate mother milk. At mother with ugly gizi generally produce slimmer irrigate mother milk in number, while the qualities of depend on food which is eating. Generally there are degradation of fat rate, vitamin and carbohydrate. This study aims to know the relationship between the status of breastfeeding mothers with the adequacy of breastfeeding. This research is analytical research with longitudinal design up (cohort). Based on the results of test statistics with the mann whitney $u$ test on the 95\% level of confidence between the nutritional status of breastfeeding mothers with the adequacy of breastfeeding showed a significant relationship $(p=0,009)$. This explains that breastfeeding mothers who have poor nutrition affect the adequacy milk product. With the results of the research above, it is expected that the health through the village midwifes for more attention on the status of maternal nutrition on the nutritional needs of breastfeeding so that breastfeeding mothers can be improved by providing more counseling related to maternal nutrition and breastfeeding, such as the provision of vitamin tablets to the blood.
\end{abstract}

Keywords: nutritional status, mother suckle, breastfeeding 


\section{LATAR BELAKANG}

Masalah gizi di Indonesia dan negara berkembang umumnya didominasi oleh masalah KEP, anemia besi, GAKY, KVA dan masalah obesitas terutama di kota besar. Anemia gizi umumnya dijumpai pada golongan rawan gizi yaitu ibu hamil, ibu menyusui, anak balita serta anak sekolah (Supariasa, 2002). Anemia pada ibu menyusui akan menyebabkan gangguan nutrisi dan produksi air susu ibu (ASI) menjadi kurang karena zat besi sangat dibutuhkan pada masa menyusui, bila jumlahnya kurang maka dapat menimbulkan gangguan peredaran zat nutrisi dalam tubuh ibu yang mengakibatkan gangguan pertumbuhan pada bayi (Soeharyo, 1999). Ibu dengan gizi buruk umumnya memproduksi ASI dalam jumlah yang lebih sedikit, tetapi kualitasnya tergantung pada makanan yang dimakan, umumnya terdapat penurunan kadar lemak, karbohidrat dan vitamin (Irawan, 2003).

Masalah gizi yang paling umum dijumpai pada ibu hamil dan ibu menyusui adalah anemia besi. Pada ibu menyusui sering terjadi anemia karena ibu sudah mengalami anemia selama hamil dilanjutkan saat menyusui. Hal ini didukung penelitian Yayasan Kusuma Buana tahun 2006-2007 yang menemukan 57\% anak balita di 21 Posyandu di Jakarta, Bekasi dan Sumedang menderita kekurangan zat besi dengan konsentrasi hemoglobin $<12$ $\mathrm{g} / \mathrm{dl}$, sedangkan ibu hamil $61,5 \%$, ibu menyusui $80 \%$, dan ibu balita 76,2\% (Lubis, 2008). Studi pendahuluan yang dilakukan di Posyandu Desa Karang Kedawang tanggal 13 Pebruari 2009 terhadap 12 ibu menyusui, ditemukan 9 orang (75\%) dengan status gizi kurang dan 3 orang (25\%) dengan status gizi baik. Ibu dengan gizi kurang tersebut ( 9 orang) didapatkan 4 bayi $(44,5 \%)$ berat badannya tetap, 2 bayi $(22,2 \%)$ berat badannya turun dan 3 bayi $(33,3 \%)$ berat badannya naik. Ibu yang mempunyai status gizi baik (3 orang), semua bayinya (100\%) mempunyai $\mathrm{BB}$ meningkat dibanding dengan BB bulan Januari 2009.
Ibu dengan status gizi cukup akan menimbun cadangan makanan nutrien dalam tubuh yang digunakan untuk mengimbangi kebutuhan selama laktasi. Hal ini sangat penting untuk proses adaptasi terhadap perubahan anatomi dan fisiologi bayi yang berlangsung selama bulan pertama. Pada periode ini bayi juga berkembang dengan sangat cepat, oleh karena itu dibutuhkan gizi yang tinggi. Bila kebutuhan gizi bayi tidak terpenuhi maka akan memberikan kondisi kesehatan kurang atau kondisi defisiensi yang menyebabkan pertumbuhannya tidak optimum. Kondisi defisiensi ini merupakan awal dari keadaan gizi bayi yang buruk. Gizi buruk adalah kondisi tubuh yang tampak sangat kurus karena makanan yang dimakan setiap hari tidak dapat memenuhi zat gizi yang dibutuhkan, terutama kalori dan protein. Tanda awal gizi buruk seperti berat badan anak letak titiknya dalam kartu menuju sehat (KMS) jauh berada di bawah garis merah (BGM) dan bila hal ini tidak segera ditangani maka akan terjadi KEP (Arisman, 2007). Kebutuhan gizi ibu menyusui lebih besar dibanding saat hamil. Saat menyusui diperlukan energi ekstra untuk memulihkan kondisi kesehatan setelah melahirkan, untuk aktivitas sehari-hari serta pembentukan ASI. Pada bulan pertama sesudah persalinan, produksi ASI umumnya sangat banyak sehingga akan banyak keluar diisap oleh bayi dan ibu akan lebih cepat haus serta lapar. Agar jumlah kalori yang keluar tersebut seimbang maka diperlukan masukan nutrisi yang seimbang karena energi ini akan diproses lagi untuk pembentukan ASI. Selama menyusui ibu memproduksi sekitar 800-1000 cc ASI (Paath, 2005). Jumlah produksi ASI bergantung pada besarnya cadangan lemak yang tertimbun selama hamil dan dalam batas tertentu. Rata-rata volume ASI wanita berstatus gizi baik sekitar 700-800 ml. Sementara yang berstatus gizi kurang hanya berkisar 500-600 ml. Jumlah ASI yang disekresikan pada 6 bulan pertama sebesar $750 \mathrm{ml}$ sehari. Sekresi pada hari pertama 
hanya terkumpul sebanyak $50 \mathrm{ml}$ yang kemudian meningkat menjadi 500, 650, dan $750 \mathrm{ml}$ masing-masing pada hari kelima bulan pertama dan ketiga. Volume ASI pada bulan berikutnya menyusut menjadi $600 \mathrm{ml}$. Status gizi tidak berpengaruh terhadap mutu (kecuali volume) ASI, meskipun kadar vitamin dan mineralnya sedikit lebih rendah (Arisman, 2007). Penilaian status gizi ibu hamil dan ibu menyusui meliputi pengukuran antropometri serta biokimiawi (Arisman, 2007). Status gizi ibu menyusui dapat diukur secara indeks antropometri yaitu kombinasi antara beberapa parameter seperti mengukur berat badan, tinggi badan, lingkar lengan atas serta indeks masa tubuh yaitu berat badan dibagi tinggi badan dikuadratkan. Untuk mengukur status gizi bisa dilakukan secara biokimiawi dengan pemeriksaan $\mathrm{Hb}$ (Soeharyo, 1999).

Upaya penanggulangan masalah gizi kurang yang dilakukan secara terpadu antara lain: upaya pemenuhan persediaan pangan nasional, upaya perbaikan gizi keluarga (UPGK), peningkatan upaya pelayanan gizi terpadu dalam Posyandu hingga puskesmas dan rumah sakit, pemberian makanan tambahan (PMT), pemberian kapsul vitamin A dosis tinggi, pemberian tablet besi, serta upaya fortifikasi bahan makanan dengan vitamin A, yodium, dan zat besi (Almatsier, 2002). Meskipun telah banyak upaya yang dilakukan oleh pemerintah tetapi masih banyak ditemukan ibu-ibu yang menyusui mengalami status gizi kurang bahkan buruk di Desa Karang Kedawang sehingga peneliti tertarik untuk melakukan penelitian tentang korelasi antara status gizi ibu menyusui dengan kecukupan ASI di desa tersebut.

\section{METODE}

Penelitian ini menggunakan desain korelasional dengan pendekatan cross sectional. Tehnik pengambilan sample menggunakan simple random sampling dengan besar sample sebanyak 54 orang. Populasi ibu menyusui di Desa Karang
Kedawang sebanyak 73 orang. Sedangkan untuk menentukan besar sample menggunakan rumus yaitu $\mathrm{n}=\left[4 .(\mathrm{Z} 1 / 2 \text { á })^{2}\right.$ . p . (1-p) ] : $W^{2}$.Karakteristik responden terdiri dari: ibu menyusui yang mempunyai bayi berusia 1-6 bulan dan berkunjung di posyandu; ibu yang memberikan ASI eksklusif; ibu yang memiliki anak d-3 orang; ibu dapat menyusui bayinya dengan benar (areola mammae masuk semua dalam mulut bayi, keadaan puting susu menonjol, bayi menyusu pada kedua payudara secara bergantian) ibu segera menyusui bayinya setelah lahir; berat badan lahir e- 2500 gram; dan bayi lahir cukup bulan (aterm). Untuk mengetahui karakteristik responden dilakukan dengan wawancara dan observasi saat ibu menyusui bayinya.

Penelitian dilaksanakan pada bulan MeiJuni 2009 bertempat di posyandu Desa Karang Kedawang Kecamatan Sooko Kabupaten Mojokerto.

Data diperoleh dari data primer dan data sekunder. Data sekunder didapatkan dari Polindes dan Puskesmas Sooko mengenai jumlah ibu yang mengalami gizi kurang atau buruk dan sedang menyusui. Sedangkan data primer didapat dengan melakukan wawancara dan pengukuran BMI (TB, BB ibu), LILA, kadar $\mathrm{Hb}$, serta mengobservasi kecukupan ASI. Untuk kecukupan ASI diukur dengan 3 indikator yaitu mengobservasi tanda kecukupan ASI, menimbang BB bayi sebelum dan sesudah menyusu serta menimbang kenaikan BB bayi setelah 1 bulan. Proses pengumpulan data dilakukan oleh peneliti sendiri kecuali pemeriksaan $\mathrm{Hb}$ dilakukan oleh petugas laboratorium yang diukur dengan metode cyanmeth. Pada awal penelitian responden diberikan pertanyaan untuk mengetahui identitas dan karakteristik responden kemudian melakukan pengukuran tentang BB, TB ibu untuk mengetahui IMB, mengukur LILA, mengobservasi tanda kecukupan ASI, menimbang BB bayi sebelum dan sesudah menyusu dan dicatat pada lembar yang telah disediakan, setelah 
melakukan pengukuran, responden diberi pertanyaan mengenai keluhan yang dirasakan (bila ada). Alat yang digunakan untuk menimbang $\mathrm{BB}$ ibu dengan timbangan pegas, untuk BB bayi dengan timbangan Dacin, TB ibu dengan alat khusus untuk mengukur TB, mengukur LILA dengan pita ukur dari Depkes. Semua alat telah dilakukan uji validitas sebelumnya.

Semua data yang telah terkumpul diproses dan diolah baik secara manual maupun melalui komputer dengan menggunakan uji analisa statistik dengan komputer. Dilakukan analisis data secara deskriptif yaitu dengan menggambarkan masing-masing variabel dalam bentuk

distribusi frekuensi dan prosentase. Untuk mengetahui tingkat signifikansi adanya korelasi status gizi ibu menyusui dengan kecukupan ASI dilakukan uji mann whitney $u$ test karena variabel bebas berskala data nominal sedangkan variabel tergantung berskala data ordinal. Proposal penelitian ini telah mendapatkan persetujuan dari komite etik penelitian Universitas Airlangga Surabaya tahun 2009.

\section{HASIL DAN PEMBAHASAN}

\section{Hasil}

\section{Karakteristik Responden}

Tabel 1. Karakteristik responden berdasarkan usia, pendidikan, pekerjaan, usia bayi, jumlah anak hidup (paritas), berat badan lahir bayi, dan keikutsertaan KB.

\begin{tabular}{|c|c|c|c|}
\hline No & Karakteristik & Jumlah (n) & Prosentase (\%) \\
\hline & Usia & & \\
\hline 1 & $15-20$ th & 4 & 7,4 \\
\hline 2 & $21-25$ th & 14 & 25,9 \\
\hline 3 & $26-30$ th & 19 & 35,2 \\
\hline 4 & $31-35$ th & 13 & 24,1 \\
\hline \multirow[t]{3}{*}{5} & $36-40$ th & 4 & 7,4 \\
\hline & Total & 54 & 100 \\
\hline & Pendidikan: & & \\
\hline 1 & $\mathrm{SD} / \mathrm{MI}$ & 5 & 9,3 \\
\hline 2 & SMP/MTs & 20 & 37 \\
\hline \multirow[t]{3}{*}{3} & SMA/MA & 29 & 53,7 \\
\hline & Total & 54 & 100 \\
\hline & Pekerjaan: & & \\
\hline 1 & Tidak bekerja & 48 & 88,9 \\
\hline \multirow[t]{3}{*}{2} & Bekerja & 6 & 11,1 \\
\hline & Total & 54 & 100 \\
\hline & Usia bayi: & & \\
\hline 1 & $2-3$ bulan & 14 & 25,9 \\
\hline 2 & 3-4 bulan & 23 & 42,6 \\
\hline \multirow[t]{3}{*}{3} & 4-5 bulan & 17 & 31,5 \\
\hline & Total & 54 & 100 \\
\hline & Jumlah anak hidup: & & \\
\hline 1 & 1 orang & 14 & 25,9 \\
\hline 2 & 2 orang & 31 & 57,4 \\
\hline \multirow[t]{3}{*}{3} & 3 orang & 9 & 16,7 \\
\hline & Total & 54 & 100 \\
\hline & Berat badan lahir bayi: & & \\
\hline 1 & 2500-2999 gram & 34 & 62,9 \\
\hline 2 & 3000-3499 gram & 17 & 31,5 \\
\hline \multirow[t]{3}{*}{3} & $3500-4000$ gram & 3 & 5,6 \\
\hline & Total & 54 & 100 \\
\hline & Keikutsertaan KB: & & \\
\hline 1 & Suntik 3 bulan & 6 & 11,1 \\
\hline \multirow[t]{2}{*}{2} & Belum KB & 48 & 88,9 \\
\hline & Total & 54 & 100 \\
\hline
\end{tabular}


Dari tabel 1 didapatkan hasil karakteristik responden berdasarkan usia bahwa responden paling banyak pada kelompok usia 26-30 tahun yaitu 35,2\%.

Karakteristik responden berdasarkan pendidikan menunjukkan bahwa responden paling banyak berpendidikan SMA yaitu $53,7 \%$.

Karakteristik responden berdasarkan pekerjaan menunjukkan bahwa responden paling banyak tidak bekerja yaitu $88,9 \%$.

Karakteristik responden berdasarkan usia bayi menunjukkan bahwa usia bayi dari responden paling banyak berusia 3-4 bulan yaitu $42,6 \%$.

Tabel 2. Gambaran responden berdasarkan body mass index, lingkar lengan atas, kadar $\mathrm{Hb}$, status gizi, dan kecukupan ASI.

\begin{tabular}{|c|c|c|c|}
\hline No & Karakteristik & Jumlah (n) & Prosentase (\%) \\
\hline & Body mass index: & & \\
\hline 1 & Kurus tk berat & 2 & 3,7 \\
\hline 2 & Kurus tk ringan & 22 & 40,7 \\
\hline 3 & Normal & 21 & 38,9 \\
\hline 4 & Gemuk tk ringan & 5 & 9,3 \\
\hline \multirow[t]{3}{*}{5} & Gemuk tk berat & 4 & 7,4 \\
\hline & Total & 54 & 100 \\
\hline & Lingkar lengan atas: & & \\
\hline 1 & Tidak beresiko KEK & 30 & 55,6 \\
\hline \multirow[t]{3}{*}{2} & Beresiko KEK & 24 & 44,4 \\
\hline & Total & 54 & 100 \\
\hline & Kadar Hb: & & \\
\hline 1 & Normal & 23 & 42,6 \\
\hline 2 & Anemia ringan & 29 & 53,7 \\
\hline \multirow[t]{3}{*}{3} & Anemia berat & 2 & 3,7 \\
\hline & Total & 54 & 100 \\
\hline & Status gizi: & & \\
\hline 1 & Baik & 52 & 96,3 \\
\hline \multirow[t]{3}{*}{2} & Buruk & 2 & 3,7 \\
\hline & Total & 54 & 100 \\
\hline & Kecukupan ASI & & \\
\hline 1 & Berlebih & 2 & 3,7 \\
\hline 2 & Cukup & 50 & 92,6 \\
\hline \multirow[t]{2}{*}{3} & Kurang & 2 & 3,7 \\
\hline & Total & 54 & 100 \\
\hline
\end{tabular}

Dari tabel 2 didapatkan hasil gambaran responden berdasarkan body mass index menunjukkan bahwa responden paling banyak mempunyai body mass index adalah kurus tingkat ringan yaitu 40,7\%. BMI adalah ukuran indeks massa tubuh yang diukur melalui ukuran BB dan TB kemudian hasilnya
Karakteristik responden berdasarkan jumlah anak hidup menunjukkan bahwa responden paling banyak mempunyai anak 2 orang yaitu $57,4 \%$.

Karakteristik responden berdasarkan BB lahir bayi menunjukkan bahwa responden paling banyak mempunyai bayi dengan BB lahir 2500-2999 yaitu 62,9\%.

Karakteristik responden berdasarkan keikutsertaan KB menunjukkan bahwa responden paling banyak belum mengikuti KB setelah melahirkan yaitu $88,9 \%$.

\section{Status Gizi Ibu Menyusui}


(kekurangan energi kronis) yaitu 55,6\%. LILA adalah ukuran lingkar lengan atas responden yang diukur dengan pita ukur dari Depkes dengan kriteria Tidak beresiko KEK bila e" 23,5 cm dan beresiko KEK bila $<23,5$ $\mathrm{cm}$.

Gambaran responden berdasarkan kadar $\mathrm{Hb}$ menunjukkan bahwa responden paling banyak menderita anemia ringan yaitu 53,7\%. Kadar $\mathrm{Hb}$ adalah ukuran $\mathrm{Hb}$ responden yang diukur dengan metode cyanmeth kemudian hasilnya dimasukkan dalam kategori yang sudah ada yaitu Hb normal e" 11 gram/dl, anemia ringan 8-11 gram/dl dan anemia berat $<8$ gram/dl.

Gambaran responden berdasarkan status gizi menunjukkan bahwa status gizi ibu menyusui paling banyak adalah baik yaitu $96,3 \%$. Status gizi ibu menyusui adalah ukuran status gizi yang dilihat melalui tiga indikator yaitu ukuran BMI, LILA dan kadar $\mathrm{Hb}$.

Gambaran responden berdasarkan kecukupan ASI menunjukkan bahwa paling banyak pada tingkat cukup yaitu $92 \%$. Kecukupan ASI adalah tanda yang terlihat pada bayi melalui tiga indikator yaitu observasi tanda kecukupan ASI, menimbang BB bayi sebelum dan sesudah menyusu serta menimbang kenaikan BB bayi setelah 1 bulan.

\section{Hubungan Antara BMI Dengan Kecukupan ASI}

Tabel 3. Hubungan antara BMI dengan kecukupan ASI

\begin{tabular}{|c|c|c|c|c|c|c|c|c|}
\hline \multirow[t]{3}{*}{ BMI } & \multicolumn{8}{|c|}{ Kecukupan ASI } \\
\hline & \multicolumn{2}{|c|}{ Berlebih } & \multicolumn{2}{|c|}{ Cukup } & \multicolumn{2}{|c|}{ Kurang } & \multicolumn{2}{|c|}{ Total } \\
\hline & n & $\%$ & $\mathbf{n}$ & $\%$ & n & $\%$ & $\mathbf{n}$ & $\%$ \\
\hline Gemuk B & 0 & 0 & 4 & 100 & 0 & 0 & 4 & 100 \\
\hline Gemuk R & 0 & 0 & 5 & 100 & 0 & 0 & 5 & 100 \\
\hline Normal & 1 & 4,8 & 20 & 95,2 & 0 & 0 & 21 & 100 \\
\hline Kurus R & 1 & 4,6 & 20 & 90,8 & 1 & 4,6 & 22 & 100 \\
\hline Kurus B & 0 & 0 & 1 & 50 & 1 & 50 & 2 & 100 \\
\hline
\end{tabular}

Dari tabel 3 didapatkan responden paling banyak mengalami BMI normal dan kurus tingkat ringan dengan kecukupan ASI cukup yaitu masing-masing 20 orang. Hasil analisa statistik dengan uji spearman rank correlations pada tingkat kepercayaan 95\% antara BMI dengan kecukupan ASI menunjukkan hubungan yang tidak bermakna $(\mathrm{p}=0,129)$. Jadi tidak ada korelasi antara BMI dengan kecukupan ASI.

\section{Hubungan Antara LILA Dengan}

Kecukupan ASI

Tabel 4. Hubungan antara LILA dengan kecukupan ASI

\begin{tabular}{|c|c|c|c|c|c|c|c|c|}
\hline \multirow[t]{3}{*}{ LILA } & \multicolumn{8}{|c|}{ Kecukupan ASI } \\
\hline & \multicolumn{2}{|c|}{ Berlebih } & \multicolumn{2}{|c|}{ Cukup } & \multicolumn{2}{|c|}{ Kurang } & \multicolumn{2}{|c|}{ Total } \\
\hline & $\mathbf{n}$ & $\%$ & $\mathbf{n}$ & $\%$ & $\mathbf{n}$ & $\%$ & $\mathbf{n}$ & $\%$ \\
\hline Takberesiko & 1 & 3,3 & 29 & 96,7 & 0 & 0 & 30 & 100 \\
\hline Beresiko & 1 & 4,1 & 21 & 87,7 & 2 & 8,2 & 24 & 100 \\
\hline
\end{tabular}

Dari tabel 4 didapatkan responden paling banyak tidak beresiko KEK dengan kecukupan ASI cukup yaitu 96,7\%. Hasil analisa statistik dengan uji mann whitney $u$ test pada tingkat kepercayaan $95 \%$ antara LILA dengan kecukupan ASI menunjukkan hubungan yang tidak bermakna $(\mathrm{p}=0,319)$.
Jadi tidak ada korelasi antara LILA dengan kecukupan ASI.

\section{Hubungan Antara Kadar Hb Dengan Kecukupan ASI}


Tabel 5. Hubungan antara kadar $\mathrm{Hb}$ dengan kecukupan ASI

\begin{tabular}{lcccccccc}
\hline Kadar Hb & \multicolumn{10}{c}{ Kecukupan ASI } & \multicolumn{2}{c}{ Total } \\
\cline { 2 - 9 } & \multicolumn{2}{c}{ Berlebih } & \multicolumn{2}{c}{ Cukup } & Kurang & n & \% \\
\cline { 2 - 10 } & n & \% & \% & n & \% & n \\
Normal & 2 & 9,2 & 20 & 90,8 & 0 & 0 & 2 & 100 \\
An ringan & 0 & 0 & 29 & 96,7 & 1 & 3,3 & 30 & 100 \\
An berat & 0 & 0 & 1 & 50 & 1 & 50 & 2 & 100 \\
\hline
\end{tabular}

Dari tabel 5 paling banyak mengalami anemia ringan dengan kecukupan ASI cukup yaitu $96,7 \%$. Hasil analisa statistik dengan uji spearman rank correlations pada tingkat kepercayaan $95 \%$ antara $\mathrm{Hb}$ dengan kecukupan ASI menunjukkan hubungan yang bermakna $(p=0,005)$. Jadi ada korelasi antara kadar $\mathrm{Hb}$ dengan kecukupan ASI.

\section{Hubungan Antara Status Gizi Dengan Kecukupan ASI}

Tabel 6. Hubungan antara status gizi dengan kecukupan ASI

\begin{tabular}{lcccccccc}
\hline Status gizi & \multicolumn{10}{c}{ Kecukupan ASI } \\
\cline { 2 - 10 } & \multicolumn{2}{c}{ Berlebih } & \multicolumn{2}{c}{ Cukup } & Kurang & \multicolumn{2}{c}{ Total } \\
\cline { 2 - 10 } & n & \% & n & \% & n & \% & n & \% \\
\hline Baik & 2 & 3,8 & 49 & 94,3 & 1 & 1,9 & 52 & 100 \\
Buruk & 0 & 0 & 1 & 50 & 1 & 50 & 2 & 100 \\
\hline
\end{tabular}

Dari tabel 6 didapatkan responden paling banyak mengalami status gizi baik dengan kecukupan ASI cukup yaitu 94,3\%. Hasil uji analisa statistik dengan uji mann whitney $u$ test pada tingkat kepercayaan $95 \%$ antara status gizi dengan kecukupan ASI menunjukkan hubungan yang bermakna $(\mathrm{p}=$ $0,009)$. Jadi ada korelasi antara status gizi ibu menyusui dengan kecukupan ASI.

\section{Pembahasan}

\section{Body Mass Index (BMI)}

Hasil analisa statistik dengan uji spearman rank correlations pada tingkat kepercayaan $95 \%$ antara BMI dengan kecukupan ASI menunjukkan hubungan yang tidak bermakna $(\mathrm{p}=0,129)$. Jadi tidak ada korelasi antara BMI dengan kecukupan ASI.

BMI adalah ukuran indeks massa tubuh yang diukur melalui ukuran BB dan TB kemudian hasilnya dibandingkan dengan tabel klasifikasi BMI yaitu gemuk berat bila >27, gemuk ringan 25-27, normal 18,5-25, kurus ringan 17-18,5 dan kurus berat $<17$.

Pada ibu menyusui dapat terjadi gizi kurang ataupun gizi lebih. Umumnya penyebab langsung gizi kurang adalah asupan makanan yang kurang termasuk proses pengolahan dan pemasakan makanan karena berpengaruh terhadap kandungan zat gizi bahan makanan tersebut terutama vitamin dan mineral (Supariasa, 2002). Untuk proses pembentukan ASI maka cadangan zat gizi pada tubuh dipergunakan sehingga semakin lama ibu menjadi kurus dan dalam keadaan tertentu ibu dapat menderita kurang gizi (Paath, 2005). Keteraturan memberikan ASI akan membantu penurunan BB ibu sekitar 0,5$1,0 \mathrm{~kg}$ tiap bulan. Penurunan BB ini tidak boleh melebihi $2 \mathrm{~kg} /$ bulan karena dapat mempengaruhi produksi ASI (Arisman, 2007). Menurut Mackey et al (1998) menyatakan bahwa asupan kalori yang < 1500-1700 kkal per hari dapat mengurangi $15 \%$ volume ASI yang diproduksi sehingga merekomendasikan bahwa ibu menyusui tidak boleh melakukan diet untuk menurunkan BB.

Menurut peneliti, tidak ada korelasi antara BMI dengan kecukupan ASI karena sebagian besar responden telah mempunyai anak sebelumnya (sebagian besar responden mempunyai $>2$ anak) sehingga telah berpengalaman untuk menyusui. Ditunjang 
kebiasaan ibu-ibu menyusui untuk memakan sayuran berwarna hijau atau daun katuk yang sangat bermanfaat untuk memperlancar produksi ASI.

\section{Lingkar Lengan Atas (LILA)}

Hasil analisa statistik dengan uji Mann Whitney pada tingkat kepercayaan 95\% antara LILA dengan kecukupan ASI menunjukkan hubungan yang tidak bermakna $(\mathrm{p}=0,319)$. Jadi tidak ada korelasi antara LILA dengan kecukupan ASI.

LILA adalah ukuran lingkar lengan atas responden yang diukur dengan pita ukur dari Depkes dengan kriteria Tidak beresiko KEK bila e" 23,5 cm dan beresiko KEK bila < 23,5 $\mathrm{cm}$.

Pengukuran LILA pada kelompok wanita usia subur (WUS) adalah salah satu cara deteksi dini yang mudah dan dapat dilaksanakan oleh masyarakat umum untuk mengetahui kelompok beresiko kekurangan energi kronis (KEK). Pengukuran LILA merupakan salah satu pilihan untuk penentuan status gizi karena mudah dilakukan dan tidak memerlukan alat-alat yang sulit diperoleh serta harganya murah (Supariasa, 2002).

Menurut Johannes (2005) menemukan bahwa tidak ada pengaruh antara status gizi ibu menyusui (LILA) terhadap eksklusifitas menyusui. Responden penelitian ada 80 orang, dibagi dalam 2 kelompok yaitu kelompok beresiko KEK ada 34 orang dan kelompok tidak beresiko KEK yang ditandai ukuran LILA e" $23,5 \mathrm{~cm}$ ada 46 orang. Didapatkan $\mathrm{p}=0,53$ yang berarti tidak ada pengaruh antara ibu yang KEK maupun non KEK terhadap eksklusifitas menyusui.

Menurut peneliti, responden sebagian besar tidak beresiko KEK karena pengukuran LILA hanya ada 2 kategori sehingga responden yang mengalami kegemukan dan BB normal masuk dalam kategori tidak beresiko KEK. Ditunjang kebiasaan ibu-ibu Desa Karang Kedawang, bila mengambil air di sumur dengan menggunakan peralatan tradisional (ember) untuk kegiatan sehari-hari seperti cuci, mandi, masak, dll. Bila musim panen padi maupun hasil pertanian lainnya (kacang panjang, jagung, ketela pohon) ikut mengangkat hasil pertanian ke rumahnya atau membantu menumbuk padi. Pada musim kemarau, mengambil air dari sumur kemudian dibawa ke kebunnya untuk menyiram agar hasil panennya bagus. Sehingga umumnya ibu-ibu mempunyai ukuran lingkar lengan atas yang besar (e" 23,5 cm).

\section{Kadar Hb}

Hasil analisa statistik dengan uji spearman rank correlations pada tingkat kepercayaan $95 \%$ antara $\mathrm{Hb}$ dengan kecukupan ASI menunjukkan hubungan yang bermakna $(p=0,005)$. Jadi ada korelasi antara kadar $\mathrm{Hb}$ dengan kecukupan ASI.

Kadar $\mathrm{Hb}$ adalah ukuran $\mathrm{Hb}$ responden yang diukur dengan metode cyanmeth kemudian hasilnya dimasukkan dalam kategori yang sudah ada yaitu $\mathrm{Hb}$ normal e" 11 gram/ $\mathrm{dl}$, anemia ringan 8-11 gram/dl dan anemia berat $<8$ gram $/ \mathrm{dl}$.

Pemeriksaan biokimia dalam penilaian status gizi memberikan hasil yang lebih tepat dan obyektif daripada hanya menilai konsumsi pangan atau pemeriksaan antropometri saja. Pemeriksaan biokimia yang sering digunakan adalah tehnik pengukuran kandungan berbagai zat gizi dan substansi kimia lain dalam darah (misal pemeriksaan $\mathrm{Hb}$ ). $\mathrm{Hb}$ adalah parameter yang digunakan secara luas untuk menetapkan prevalensi anemia (Supariasa, 2002).

Peningkatan kebutuhan akan zat besi untuk pembentukan sel darah merah yang lazim berlangsung pada masa pertumbuhan bayi, pubertas, masa kehamilan dan menyusui. Selama menyusui, zat besi yang seharusnya hilang bersama darah haid dialihkan sebagian $( \pm 0,3 \mathrm{mg})$ kedalam ASI sebagai tambahan kehilangan basal. Peningkatan kebutuhan akan zat besi untuk pembentukan sel darah merah yang lazim berlangsung pada masa 
pertumbuhan bayi, pubertas, masa kehamilan dan menyusui (Arisman, 2007).

Menurut Wahyuni (2004) menemukan bahwa prevalensi anemia besi yang terbesar adalah pada wanita hamil dan menyusui yaitu 50-70\% dibanding dengan wanita yang tidak hamil atau menyusui. Dari SKRT (1995) dikatakan bahwa prevalensi anemia besi ratarata nasional ibu hamil adalah $63,5 \%$ yang terus berlanjut sampai proses menyusui. Menurut Soemantri (1983) menyatakan bahwa anemia dipengaruhi oleh faktor ekonomi, pendidikan, status gizi, pola makan, fasilitas kesehatan serta daya tahan tubuh.

Menurut peneliti, responden sebagian besar mengalami anemia ringan karena umumnya ibu-ibu mempunyai kebiasaan mengonsumsi makanan yang dapat mengganggu penyerapan zat besi (seperti kopi, teh yang banyak mengandung ca oxalate) secara bersamaan pada waktu atau setelah makan sehingga menyebabkan serapan zat besi semakin rendah. Komposisi makanan yang sebagian besar terdiri dari nasi dengan menu yang kurang beragam sehingga asupan zat besi rendah.

\section{Kecukupan ASI}

Kecukupan ASI dapat dilihat dari tanda yang terlihat pada bayi seperti pengeluaran ASI, frekuensi menyusu, kenaikan berat badan bayi, keadaan buah dada serta frekuensi bayi mengompol (Purwanti, 2004). Berat badan lahir juga mempengaruhi kecukupan ASI karena berkaitan dengan kekuatan mengisap, frekuensi dan lama penyusuan (Arisman, 2007).

Ada beberapa sayuran yang dapat memperbanyak pengeluaran ASI yaitu daun katuk, sawi dan kacang-kacangan (Paath, 2005). Cara pengolahan dan pemasakan sayuran juga mempengaruhi kandungan zat gizi terkandung.

Kecukupan ASI juga dipengaruhi oleh refleks yang berperan dalam pembentukan dan pengeluaran ASI, yaitu refleks prolaktin dan oksitosin. Faktor yang dapat meningkatkan refleks oksitosin antara lain: melihat bayi, mendengarkan suara bayi, mencium bayi, memikirkan untuk menyusu bayi serta isapan bayi. Sedangkan faktor yang dapat meningkatkan refleks prolaktin antara lain: rangsangan atau isapan bayi. Bila kedua refleks tersebut berjalan dengan baik maka produksi ASI akan tetap berlangsung. Disamping itu, jumlah paritas juga mempengaruhi produksi ASI yang dihasilkan (Soetjiningsih, 1997).

Produksi ASI dirangsang oleh pengosongan payudara, berlaku prinsip supply and demand, sehingga makin banyak ASI dikeluarkan, maka makin banyak pula ASI diproduksi. ASI diproduksi sesuai dengan jumlah permintaan dan kebutuhan bayi. Selama bayi masih melanjutkan permintaannya akan ASI (dengan masih mengisap ASI), selama itu payudara ibu akan tetap melanjutkan produksinya. Apabila bayi berhenti mengisap, maka payudara ibu pun akan berhenti memproduksi ASI (Erlina, 2008).

Hasil penelitian menunjukkan bahwa sebagian besar responden cukup untuk kecukupan ASI yaitu 92,6\%. Hal ini menjelaskan bahwa kecukupan ASI dipengaruhi oleh kekuatan, frekuensi, dan lama penyusuan sehingga produksi ASI terus berjalan.

Penelitian dari Bailey KV di New Guinea (1995) ditemukan bahwa kenaikan jumlah anak menyebabkan perubahan terhadap volume ASI yang dihasilkan. Pada anak pertama sampai keempat volume ASI akan meningkat, sedangkan pada anak kelima dan seterusnya mengalami penurunan volume ASI (Supariasa, 2002).

Menurut peneliti, responden sudah berpengalaman dalam menyusui bayinya karena sebagian besar responden sudah mempunyai anak $>1$ yaitu 57,4\%. Ditunjang kebiasaan mengonsumsi sayuran yang dapat meningkatkan produksi ASI seperti daun katuk, dan kacang-kacangan. Selain itu, cara 
menyusui yang benar yang telah diajarkan oleh bidan saat persalinan, dilaksanakan oleh responden sehingga produksi ASI terus meningkat. Dan pendidikan responden yang sebagian besar SMA/MA sehingga mudah menerima dan memahami penjelasan yang diberikan oleh bidan.

\section{Hubungan Status Gizi Ibu Menyusui Dengan Kecukupan ASI}

Status gizi merupakan keadaan tubuh sebagai akibat konsumsi makanan dan penggunaan zat gizi (Almatsier, 2002). Gizi berfungsi sebagai sumber utama energi atau kalori yang berguna untuk metabolisme tubuh, kerja organ tubuh (seperti aktivitas fisik), melancarkan metabolisme tubuh, memberikan kekebalan tubuh untuk melawan penyakit atau resiko terkena penyakit serta untuk mengganti sel-sel yang baru (Eisenberg, 1999).

Faktor yang mempengaruhi status gizi yaitu konsumsi makanan dan tingkat kesehatan. Konsumsi makanan dipengaruhi oleh pendapatan dan tersedianya bahan makanan. Selain itu dipengaruhi oleh internal (genetik, riwayat obstetrik) dan eksternal (asupan makanan, obat-obatan, lingkungan) (Supariasa, 2002).

Penilaian status gizi secara langsung salah satunya dengan mengukur antropometri. Antropometri secara umum digunakan untuk melihat ketidakseimbangan asupan protein dan energi. Ketidakseimbangan ini terlihat pada fisik (BB, TB) dan proporsi jaringan tubuh (LILA). Untuk menunjang antropometri dilakukan pemeriksaan biokimia agar memberikan hasil yang lebih tepat dan obyektif daripada hanya menilai antropometri saja.

Menurut Yayak Dyah (2006) menemukan adanya hubungan antara gizi ibu menyusui dengan berat badan bayi usia 1-4 bulan. Status gizi ibu dilihat dengan mengukur BB ibu menyusui. Responden penelitian sebanyak 15 orang. Ibu dengan status gizi tidak baik ada 6 orang (40\%), semuanya mempunyai bayi dengan BB kurang. Ibu dengan gizi baik ada 9 orang (60\%), hanya 1 orang mempunyai bayi dengan BB kurang dan 8 ibu mempunyai bayi dengan $\mathrm{BB}$ sesuai usia.

Menurut Admin (2007) menyatakan bahwa tidak ada pengaruh antara status gizi ibu menyusui dengan volume ASI. Status gizi ibu menyusui diukur dengan mengukur indeks massa tubuh. Ibu menyusui yang kurus, normal maupun gemuk tetap dapat menghasilkan volume ASI yang cukup untuk bayinya (Litbang, 2000).

Hasil uji analisa statistik dengan uji mann whitney $u$ test pada tingkat kepercayaan $95 \%$ antara status gizi ibu menyusui dengan kecukupan ASI menunjukkan hubungan yang bermakna $(p=0,009)$. Hal ini menjelaskan bahwa ibu menyusui dengan gizi buruk akan mempengaruhi kecukupan ASInya karena tubuh membutuhkan zat gizi yang cukup untuk memproduksi ASI tetapi tubuh tidak dapat memenuhi sehingga zat gizi tersebut diambil dari tubuh ibu sehingga makin lama ibu akan mengalami gizi yang bertambah buruk.

Saat dilakukan uji statistik antara BMI dengan kecukupan ASI maupun LILA dengan kecukupan ASI didapatkan hasil yang tidak bermakna ( $\mathrm{p}=0,129$ dan $\mathrm{p}=0,319)$. Sedangkan pada uji statistik antara $\mathrm{Hb}$ dengan kecukupan ASI didapatkan hasil yang bermakna $(p=0,005)$. Jadi, bila dicari yang paling berpengaruh terhadap kecukupan ASI adalah kadar $\mathrm{Hb}$ ibu menyusui. Hal ini disebabkan saat menyusui kebutuhan akan zat besi meningkat sehingga bila kadar zat besi dalam darah kurang akan mempengaruhi kecukupan ASI. Ibu menyusui yang mengalami anemia akan terganggu dalam penyerapan nutrisi dan akhirnya dapat mempengaruhi produksi ASI.

\section{KESIMPULAN DAN SARAN}

Ibu menyusui dengan gizi buruk akan mempengaruhi kecukupan ASI karena tubuh membutuhkan zat gizi yang cukup untuk 
memproduksi ASI tetapi tubuh tidak dapat memenuhi sehingga zat gizi tersebut diambil dari tubuh ibu sehingga makin lama ibu akan mengalami gizi yang bertambah buruk. Ada hubungan antara status gizi ibu menyusui dengan kecukupan ASI.

Saran yang dapat diberikan kepada petugas kesehatan yaitu memberikan penyuluhan tentang pentingnya asupan makanan yang mengandung zat besi untuk meningkatkan status gizi ibu menyusui, penyuluhan tentang faktor yang dapat menghambat atau meningkatkan penyerapan zat besi dalam tubuh, menghilangkan kebiasaan minum the/kopi setelah makan untuk penyerapan zat besi dalam tubuh serta pemberian vitamin yang mengandung zat besi (tablet tambah darah) untuk ibu menyusui karena kebutuhan zat besi yang meningkat selama menyusui bayinya.

\section{DAFTAR PUSTAKA}

Akre, J. 1994. Pemberian Makanan Untuk Bayi. Jakarta: Perinasia.

Almatsier, S. 2002. Prinsip Dasar Ilmu Gizi. Jakarta: PT. Gramedia Pustaka Utama.

Arisman. 2007. Gizi Dalam Daur Kehidupan. Jakarta: EGC.

BKKBN Propinsi Jawa Timur. 2006. Panduan Materi dan KIE Menuju Kehamilan yang Aman dan Sehat. Surabaya: BKKBN.

Cameron. 1983. Manual on Feeding Infants and Young Children. Nairobi: Oxford University Press.

Djaeni, A. 2000. Ilmu Gizi, Jakarta: Dian Rakyat.

Erlina. 2008. Produksi ASI dan Faktor yang Mempengaruhinya. 12 Oktober. Available from: http:// kuliah_bidan.wordpress.com. Diakses tanggal 20 Desember 2008.

Erlina. 2008. Prolaktin (Hormon yang Menghasilkan ASI). 19 September. Available from: http:// kuliah_bidan.wordpress.com. Diakses tanggal 20 Desember 2008.
Erlina. 2008. Apakah Bayiku Sudah Cukup Mendapatkan ASI?. 19 Juli. Available from: http:// kuliah_bidan.wordpress.com. Diakses tanggal 10 Januari 2009.

Falkner. 1991. Infant and Child Nutrition Worldwide Issues and Perspectives. Boca Raton. Florida: CRC press.

Irawan, R. 2003. Pola Dasar Makanan Bayi dan Anak. Surabaya: RSUD Dr. Soetomo.

Irwan. 2008. Praktek Menyusui yang Benar. 6 Pebruari. Available from: http:// dokteranakku.com. Diakses tanggal 24 Desember 2008.

Lubis. 2008. Cegah Anemi pada Ibu dan Anak di Pulau Seribu. 3 Juli. Available From: http://ipmg online.com. Diakses tanggal 20 Januari 2009.

Mutalazimah. 2005. Hubungan Lingkar Lengan Atas dan Kadar $\mathrm{Hb}$ dengan BBLR di RSUD DR. Moewardi. Surakarta: Jurnal Penelitian Sains \& Teknologi Vol 6 No.2: 114-126.

Paath. 2005. Gizi Dalam Kesehatan Reproduksi. Jakarta: EGC.

Pudjiati, S. 2001. Ilmu Gizi Klinis Pada Anak. Jakarta: Balai Penerbit FKUI.

Satyanegara. 2005. Panduan Lengkap Perawatan untuk Bayi dan Balita. Jakarta: Arcan.

Soeharyo. 1999. Masalah Kurang Gizi Pada Ibu Hamil, Ibu Menyusui dan Anak Balita serta Akibatnya. Seminar: Peningkatan Pengetahuan dan Ketrampilan Gizi Keluarga di Masa Krisis. Semarang: 27 Oktober 1999.

Sugiono. 2008. Metode Penelitian Kuantitatif, Kualitatif dan R\&D. Bandung: CV. Alfabeta.

Supariasa, I.D.N. 2002. Penilaian Status Gizi. Jakarta: EGC.

Wahyuni. 2004. Masalah Kurang Gizi di Indonesia. 3 April. Available From: http:/ Igizi-net.com. Diakses tanggal 20 Januari 2009.

Windhu. 2008. Metode Penelitian Kuantitatif. Surabaya: Universitas Airlangga. 
Yayak. 2006. Hubungan antara Gizi Ibu Menyusui dengan Berat Badan Bayi Usia 1-4 Bulan di Malang. Malang: Karya Tulis Ilmiah Poltekkes Malang. 